\title{
KARAKTERISASI KOPI ARABIKA (Coffea arabica L.) HASIL FERMENTASI DENGAN BAKTERI ASAM LAKTAT (Lactobacillus sp)
}

\author{
Zakia Arachmah Siregar ${ }^{1)}$, RTM Suthamihardja ${ }^{1)}$, Devy Susanty ${ }^{1}$ * \\ ${ }^{1)}$ Program Studi Kimia, Fakultas MIPA, Universitas Nusa Bangsa \\ Jl.KH Sholeh Iskandar Km 4, Tanah Sareal, Bogor 16166, Indonesia \\ *e-mail: dvsusanty@ gmail.com
}

\author{
ABSTRACT \\ Characterization of Fermented Arabic Coffee (Coffea Arabica L.) \\ with Lacto Acid Bacteria (Lactobacillus Sp)
}

\begin{abstract}
Coffee bean fermentation is one of a series of processes for making ground coffee that can affect coffee quality. In this study the fermentation of Arabica coffee beans was carried out using lactic acid bacteria (Lactobacillus sp) in the form of a starter. The analysis was carried out on five samples, namely brand a coffee samples (sample A), coffee samples processed without bacteria (sample B), coffee samples processed with the addition of bacteria and substrate as many as 10:90 (sample C), 20:80 (sample D), 30:70 (sample E). The five coffee samples were analyzed for water content, $\mathrm{pH}$, extract content, ash content, and caffeine content. Identification of caffeine was carried out by the UV-Vis spectrophotometric method at a wavelength of $275.0397 \mathrm{~nm}$. The highest caffeine content was in sample $C$ at $0.95 \%$ and the lowest caffeine content was in sample E 0.71\%. The highest extract content was found in sample E at $27.72 \%$ and the lowest content in $C$ at $24.60 \%$. The highest water content results were found in sample $C$ of $4.56 \%$ and the lowest in sample E of $4.26 \%$. The highest ash content was found in coffee $C$ samples at $4.98 \%$ and the lowest ash content in $E$ at $4.43 \%$. The highest value of the degree of acidity $(p H)$ was found in sample B (6.19) and the lowest in sample A (5.41). The results showed that the Arabica ground coffee met the SNI 01-3542-2004 requirements on parameters of moisture content, extract content, ash content and caffeine content.
\end{abstract}

Keywords: Arabica coffee, fermentation, Lactobacillus sp, Caffeine

\begin{abstract}
ABSTRAK
Fermentasi biji kopi merupakan salah satu rangkaian proses pengolahan pembuatan kopi bubuk yang dapat mempengaruhi kualitas kopi. Pada penelitian ini fermentasi biji kopi Arabica dilakukan menggunakan bakteri asam laktat (Lactobacillus sp) dalam bentuk starter. Analisis dilakukan terhadap lima sampel yaitu sampel kopi merk a (sampel A), sampel kopi yang diproses tanpa bakteri (sampel B), sampel kopi yang diproses dengan penambahan bakteri dan substrat sebanyak 10:90 (sampel C), 20:80 (sampel D), 30:70 (sampel E). Kelima sampel kopi tersebut dianalisis kadar air, pH, kadar sari, kadar abu, dan kadar kafein. Identifikasi kafein dilakukan dengan metode spektrofotometri UV-Vis pada panjang gelombang 275,0397 $\mathrm{nm}$. Kadar kafein tertinggi terdapat pada sampel C sebesar $0,95 \%$ dan kadar kafein terendah pada sampel E 0,71\%. Kadar sari tertinggi terdapat pada sampel E sebesar 27,72\% dan kadar sari terendah pada C sebesar 24,60\%. Hasil kadar air tertinggi terdapat pada sampel C sebesar 4,56\% dan kadar terendah pada sampel E sebesar 4,26\%. Kadar abu tertinggi terdapat pada sampel kopi C sebesar 4,98\% dan kadar abu terendah pada $\mathrm{E}$ sebesar 4,43\%. Nilai derajat keasaman ( $\mathrm{pH}$ ) tertinggi didapatkan pada sampel B yaitu sebesar 6,19 dan terendah pada sampel A yaitu 5,41. Hasil uji menunjukkan bahwa kopi bubuk arabika dengan proses fermentasi menggunakan bakteri asam laktat memenuhi syarat SNI 01-3542-2004 pada parameter kadar air, kadar sari, kadar abu dan kadar kafein.
\end{abstract}

Kata kunci: Kopi arabika, fermentasi, Lactobacillus sp, Kafein

https://doi.org/10.31938/isn.v10i2.285 


\section{PENDAHULUAN}

Kopi arabika (Coffea arabica L.) merupakan kopi dengan cita rasa yang paling baik dibanding jenis kopi lainnya. Biji kopi arabika berbentuk picak berukurusan besar dengan bobot 18-22 $\mathrm{g}$ tiap 100 biji. Kopi arabika mengandung 1$1,3 \%$ kafein dengan cita rasa khas dan sedikit asam (Najiyati dan Danarti, 2004). Kualitas kopi bubuk selain ditentukan oleh jenis kopinya, juga dipengaruhi oleh pengolahannya.

Kopi bubuk diperoleh melalui serangkaian kegiatan pengolahan biji kopi, yang dilanjutkan dengan proses penyanggraian dan penggilingan. Pengolahan biji kopi dapat dilakukan dengan cara kering (Ost Indische Bereiding) ataupun cara basah (Wash Indische Bereiding) (Siswaputranto, 1993). Kedua jenis pengolahan tersebut dilakukan melalui proses fermentasi (Hoffman, 2014). Menurut Panggabean (2011) proses fermentasi dilakukan untuk melepaskan lapisan lendir yang terdapat pada biji kopi. Disamping itu, pengolahan biji kopi melalui proses fermentasi dapat meningkatkan cita rasa (Towaha dan Rubiyo, 2016). Hal ini menjadikan fermentasi sebagai tahapan yang penting pada pengolahan biji.

Fermentasi biji kopi dibantu oleh adanya aktivitas mikroorganisme yang ada pada lingkungan (Frank et al., 1996). Mikroorganisme menjadikan lapisan lendir sebagai sumber nutrisi (Board, 1983), karena kaya akan pektin dan gula (Murthy dan Naidu, 2011). Kulit kopi, lendir, dan kulit tanduk kopi merupakan sumber adanya mikroorganisme. Campuran khamir (yeast) dan bakteri biasanya berperan pada proses fermentasi. Mutu kopi arabika dapat ditingkatkan dengan menambahkan kultur mikroorganisme pada proses fermentasi (Suarez - Quiroz et al., 2008). Bakteri asam laktat (Lactobacillus sp) merupakan jenis inokulan yang aman ditambahkan pada proses fermentasi karena memiliki kemampuan adaptasi pada kondisi proses pengolahan kopi, sehingga menghasilkan rasa yang khas. Menurut Usman et al. (2015), jumlah inokulum bakteri, waktu, substrat (medium) dan nilai $\mathrm{pH}$ merupakan beberapa faktor yang dapat mempengaruhi proses fermentasi. Pada penelitian ini dilakukan karakterisasi kopi arabika hasil fermentasi dengan penambahan bakteri asam laktat (Lactobacillus sp). Parameter yang dianalisis yaitu kadar air, pH, kadar sari, kadar abu, dan kadar kafein.

\section{BAHAN DAN METODE}

\section{Bahan dan Alat}

Bahan-bahan yang digunakan adalah akuades, amil alkohol, amonia $\left(\mathrm{NH}_{4} \mathrm{OH}\right)$, $\mathrm{HCl}$ pekat, etanol, feri klorida $\left(\mathrm{FeCl}_{3}\right)$, kalsium karbonat $\left(\mathrm{CaCO}_{3}\right)$, kloroform $\left(\mathrm{CHCl}_{3}\right)$, sampel biji kopi arabika yang berasal dari Cipanas, Bogor dan kopi bubuk bermerek A, pita magnesium, standar kafein, starter Lactobacillus sp.

Alat-alat yang digunakan adalah cawan porselen, desikator, oven, hotplate, inkubator, kertas saring, sudip, neraca analitik Ohaus, penangas air, peralatan gelas, $\mathrm{pH}$ meter, wajan stainless steel, spektrofotometer UV optizen, tanur thermo scientific, termometer, termometer besi, dan ayakan 60 mesh.

\section{Metode}

Tahapan metode penelitian antara lain preparasi sampel, penetapan kadar air, derajat keasaman, kadar abu, kadar sari, dan kadar kafein

\section{Preparasi sampel Kopi}

Pada penelitian ini sampel kopi yang digunakan yaitu kopi arabika dengan variasi: Kopi bubuk Arabika Merk tertentu (A); Kopi bubuk Arabika yang diproses tanpa fermentasi menggunakan bakteri asam laktat (B) ; Kopi bubuk Arabika yang diproses dengan penambahan bakteri $10 \mathrm{~mL}$ dan substrat $90 \mathrm{~mL}$ (C); Kopi bubuk Arabika yang diproses dengan penambahan bakteri $20 \mathrm{~mL}$ dan substrat $80 \mathrm{~mL}$ (D); Kopi bubuk Arabika yang diproses dengan penambahan bakteri $30 \mathrm{~mL}$ dan substrat $70 \mathrm{~mL}(\mathrm{E})$. 
2. Fermentasi (Wilujeng dan Wikandari, 2013; Usman et al., 2015; modifikasi)

\section{a. Persiapan/ Pembuatan Medium Fermentasi}

Kulit biji kopi sebagai substrat disiapkan sebanyak 200 gram, ditambahkan akuadest sebanyak $1000 \mathrm{~mL}$, kemudian dihaluskan menggunakan blender. Jumlah substrat yang digunakan pada saat fermentasi yaitu 90; 80; $70 \mathrm{~mL}$ dan di inokulasikan $10 ; 20 ; 30 \mathrm{~mL}$ starter Lactocacillus sp.

\section{b. Preparasi Fermentasi Biji Kopi Alami}

Biji kopi arabika disiapkan sebanyak 100 gram, difermentasi secara alami selama 20 jam. Biji kopi yang telah difermentasi dicuci dan dikeringkan dalam oven dengan suhu $60^{\circ} \mathrm{C}$ selama 25 jam. Biji kopi yang telah dikeringkan, kulit tanduknya dikupas kemudian biji kopi disangrai secara manual, lalu dihaluskan sehingga menjadi kopi bubuk.

\section{c. Preparasi Fermentasi Biji Kopi dengan Penambahan Bakteri Asam Laktat (BAL)}

Biji kopi arabika disiapkan sebanyak 300 gram, difermentasi dengan penambahan bakteri asam laktat (Lactobacillus sp.) masing-masing sampel ditambahkan bakteri sebanyak 10;20;30 mL dan substrat sebanyak 90; $80 ; 70 \mathrm{~mL}$ selama 20 jam. Biji kopi yang telah difermentasi dicuci dan dikeringkan dalam oven dengan suhu $60^{\circ} \mathrm{C}$ selama 25 jam. Biji kopi yang telah dikeringkan, kulit tanduknya dikupas kemudian biji kopi disangrai secara manual, lalu dihaluskan sehingga menjadi kopi bubuk.

\section{Karakterisasi Kopi Bubuk Arabika Hasil Fermentasi}

Biji kopi yang telah menjadi bubuk dilakukan pengujian kadar air, kadar sari, kadar abu dengan metode sesuai SNI 013542-2004, pengukuran $\mathrm{pH}$ dengan $\mathrm{pH}$ meter dan kadar kafein dengan metode spetrofotometri (fitri, 2008).

\section{HASIL DAN PEMBAHASAN}

\section{Kopi Hasil fermentasi dengan Bakteri Asam Laktat}

Pembuatan kopi beras (biji kopi kering) dari buah kopi dapat melalui cara basah dan cara kering. Menurut Pastianiasih (2012), pengolahan yang tidak tepat dapat mengakibatkan biji kopi terfermentasi berlebihan (fermented). Pada penelitian ini dilakukan pengolahan biji kopi secara basah. Pengolahan secara basah mendapatkan kualitas yang lebih baik dan hasil yang lebih seragam Pencucian bertujuan untuk membersihkan lendir yang melekat pada biji. Kulit kopi yang terdiri dari $80 \%$ pectin dan $20 \%$ gula dijadikan substrat pada fermentasi kopi (Muchtadi, 2010). Masing-masing sampel kopi dilakukan fermentasi anaerob fakultatif dengan menggunakan plastik. Sampel mengalami perbedaan dimana pada sampel C warna yang dihasilkan lebih coklat dibandingkan dengan sampel D dan E (Gambar 1).

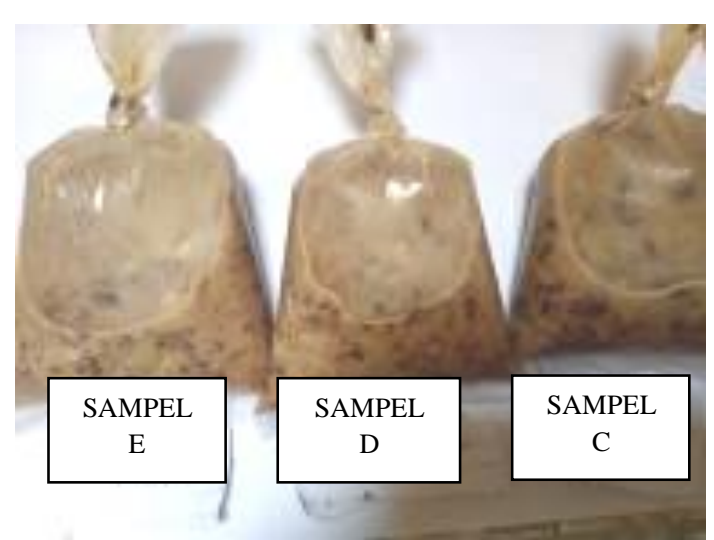

Gambar 1. Fermentasi Biji Kopi Arabika 


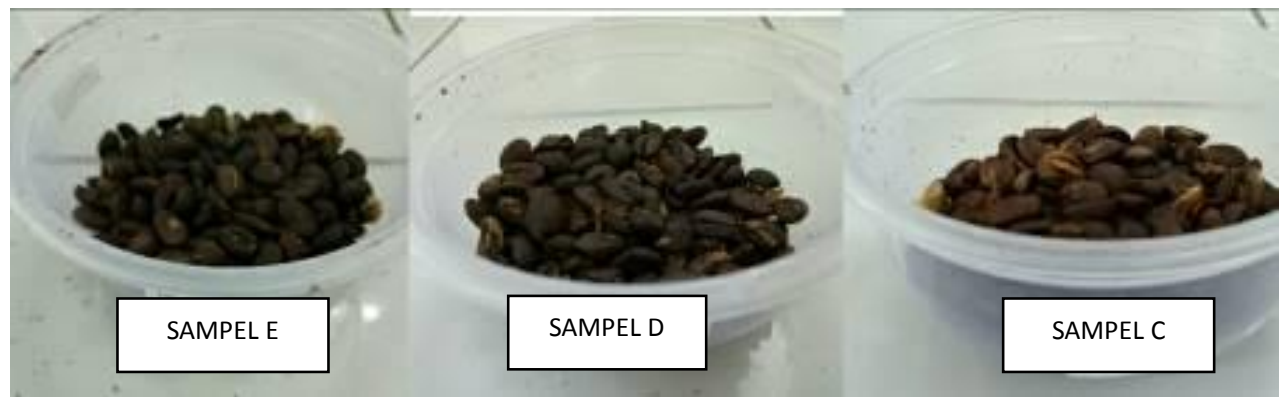

Gambar 2. Hasil Penyangraian Biji Kopi

Proses penyangraian kopi beras arabika dilakukan dengan menggunakan kompor gas dengan wajan stainless steel yang dilengkapi dengan termometer besi yang di simpan didekat api kompor. Penyangraian bisa dilakukan dengan alat mesin sangrai yang berputar secara kontinu. Biji kopi yang disangrai dengan mesin ini akan dihasilkan biji kopi yang matang secara merata dan suhu yang digunakan selama penyangraian konstan. Penyangraian dengan menggunakan sumber panas kompor tidak dapat diukur secara pasti suhunya karena kurangnya perlatan yang mendukung untuk mengukur suhu. Oleh karena itu, agar suhu pada saat penyangraian menggunakan kompor dapat terukur digunakan termometer besi yang diletakkan diapi kompor untuk mengukur suhu pada saat penyangraian. Untuk menstabilkan suhu yang terukur pada termometer dilakukan dengan cara mengatur besar kecilnya api.

Pada penelitian ini dilakukan penyangraian dengan suhu $\pm 200^{\circ} \mathrm{C}$ yang menunjukkan warna biji kopi yang dihasilkan berwarna coklat kehitaman (Gambar 2) serta aroma kopi pekat.Pada proses sangrai, dimungkinkan terjadinya perubahan kimia yang dapat dilihat dari perubahan warna biji kopi dari hijau kebiruan menjadi coklat kehitaman (Rachmawati, 2010). Menurut Panggabean (2011), biji arabika mengandung 0,6-1,3\% senyawa trigonelin yang mengalami degradasi menjadi komponen heterosiklik piridin yang memberikan aroma pada kopi. Aroma pada kopi terbentuk pada menit terakhir proses penyangraian dari hasil pirolisis gula, karbohidrat dan protein dalam sel.

Kopi bubuk diperoleh dari penggilingan kopi yang telah disangrai dengan tujuan membuka permukaan kopi sangrai hasil dari gesekan permukaan biji dengan piringan pada alat giling seperti blender (Najiyati dan Danarti, 2001). Bubuk kopi hasil penggilingan memiliki permukaan yang lebih luas sehingga meningkatkan koloid yang larut saat diseduh.

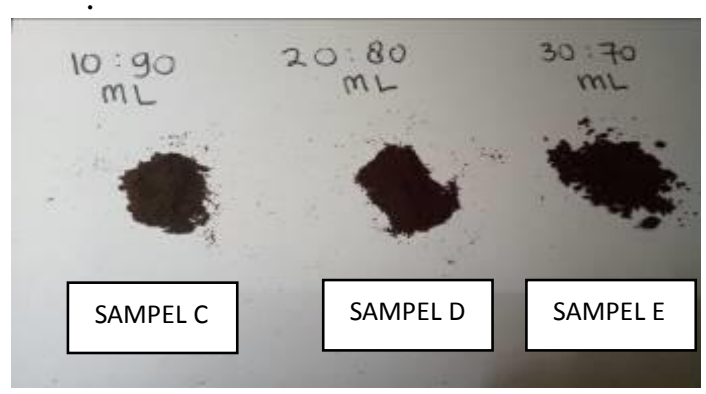

Gambar 3. Hasil Penggilingan Biji Kopi

Dari hasil (Gambar 3) terlihat bahwa ukuran partikel kopi bubuk yang diperoleh seragam karena menggunakan saringan 60 mesh. Kopi bubuk dengan ukuran partikel yang lebih besar dari 60 mesh tidak akan ikut tersaring sedangkan kopi bubuk dengan ukuran partikel 60 mesh akan tersaring sehingga akan diperoleh kopi bubuk dengan ukran yang seragam. Warna dan rasa kopi dapat dipengaruhi oleh ukuran partikelnya. Dengan ukuran yang kecil, permukaan lebih luas, sehingga komponen pada kopi lebih banyak larut saat diseduh (Yeretzian et al., 2012). Selain itu, menurut Nopitasari (2002), kandungan karbondioksida pada kopi akan lepas dengan proses penggilingan.

\section{Kadar Air}

Kandungan air yang masih tinggi dalam bahan pangan menyebabkan produk mudah mengalami kerusakan. Menurut Kustiyah (1985), kandungan air suatu bahan perlu 
untuk diketahui karena air dapat mempengaruhi penampakan, tekstur, serta citarasa bahan tersebut. Hasil pengujian kadar air pada kopi bubuk berkisar antara 1.96-4,56 \%b/b (Gambar 4). Hal ini menunjukkan bahwa kadar air masih memenuhi persyaratan yang ditetapkan pada SNI 01-3542-2004 tentang kopi bubuk yaitu maksimal 7 \%b/b.

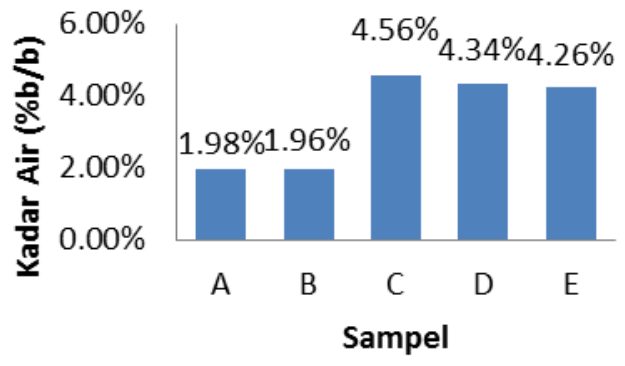

Gambar 4. Kadar Air Kopi Bubuk

Kadar air sampel C merupakan kadar air yang tertinggi yaitu sebesar $4,56 \% \mathrm{~b} / \mathrm{b}$ hal ini diduga karena pada sampel biji kopi ketika di fermentasi penambahan substratnya lebih banyak yaitu $90 \mathrm{~mL}$ yang mengandung air lebih banyak sehingga menyebabkan nilai kadar air yang dihasilkan pun lebih tinggi. Kadar air yang rendah dapat meningkatkan ketahanan pangan selama penyimpanan (Pastiniasih, 2012).

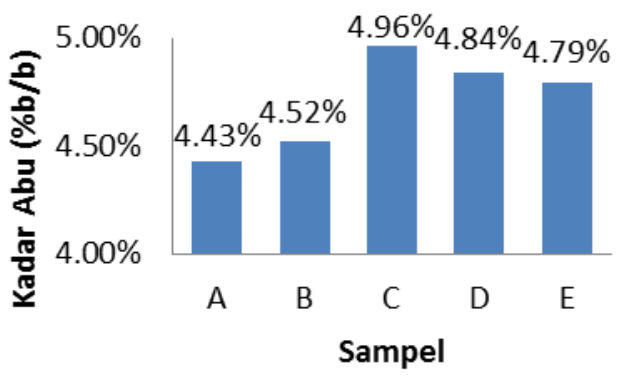

Gambar 5. Kadar Abu Kopi Bubuk

\section{Kadar Abu}

Kadar abu menunjukkan jumlah material yang terdapat dalam suatu bahan. Kandungan material pada kopi dapat berupa unsur kelumit yang dibutuhkan tanaman dalam pertumbuhan. Menurut Martin et al (1999), kandungan material dalam kopi dipengaruhi oleh kandungan hara di lingkungan tempat tumbuhnya dan penggunaan pupuk selama pemeliharaan.

Hasil pengujian kadar abu pada semua sampel kopi arabika berkisar antara 4,43 $4,96 \%$ b/b (Gambar 5). Hal ini menunjukkan bahwa kadar abu masih memenuhi persyaratan yang ditetapkan pada SNI 013542-2004 tentang kopi bubuk yaitu maksimal $5 \% \mathrm{~b} / \mathrm{b}$. Beberapa faktor yang mempengaruhi kadar abu diantaranya iklim, kondisi tanah, dan proses pemeliharaan tanaman kopi (Martin et al., 1999).

\section{Derajat Keasaman (pH)}

Sampel kopi bubuk yang diuji memiliki pH berkisar antara 5,41-6,19 (Gambar 6). Berdasarkan hasil penelitian ini, semakin banyak bakteri asam laktat yang ditambahkan semakin rendah nilai derajat keasaman. Adanya aktivitas amilolitik meningkatkan degradasi pati menjadi glukosa, yang pada akhirnya membentuk lebih banyak asam laktat pada jumlah bakteri yang lebih banyak. Banyaknya asam laktat dapat menurunkan $\mathrm{pH}$ (Wilujeng dan Wikandari, 2014). Menurut Mulato (2002) beberapa senyawa alami dalam kopi memiliki sifat mudah menguap, diantaranya asam asetat, asam format, ester, dan aldehid. Perubahan nilai $\mathrm{pH}$ dapat menjadi indikator perubahan secara kimiawi dalam biji kopi. Kandungan senyawa asam pada kopi mempengaruhi derajat keasaman kopi.

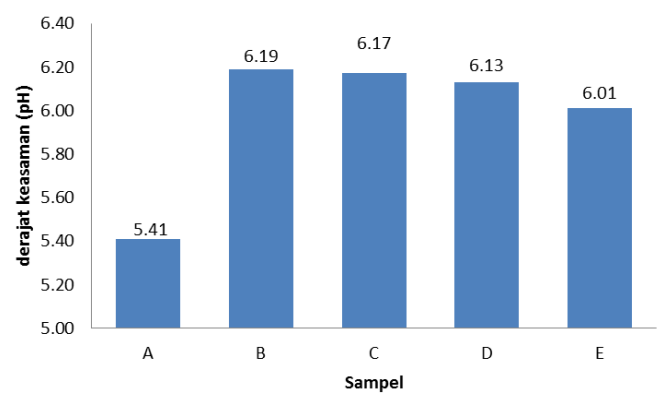

Gambar 6. Derajat Keasaman (pH)

\section{Kadar Sari}

Kadar sari menunjukkan banyaknyanya senyawa pada kopi yang dapat larut pada pelarut. Dari hasil penelitian terlihat bahwa pada sampel B, C, D, dan E masuk ke dalam persyaratan SNI 01-3542-2004 dengan batas maksimum 20-36 \% (Gambar 7). Sampel A 
memiliki nilai kadar sari lebih tinggi yaitu $41,75 \%$ masuk ke dalam persyaratan II SNI 01-3542-2004 yaitu dengan syarat maksimal kadar sari yang dihasilkan sebesar 60\%. Menurut Yeretzian et al., (2012), ukuran partikel yang halus memudahkan lepasnya komponen kopi saat diseduh. Sampel C, D dan E memiliki ukuran yang seragam karena saat penyaringan bubuk menggunakan saringan dengan ukuran yang sama. Hal ini terlihat dari kadar sari yang tidak jauh berbeda. Komponen yang lepas dari kopi terbagi atas komponen larut air dan komponen yang membentuk emulsi dengan air. Pada umumnya komponen yang larut air ada yang bersifat mudah menguap sehingga memberikan aroma khas pada penyeduhan kopi (Buffo dan Cardelli-Freire 2004).

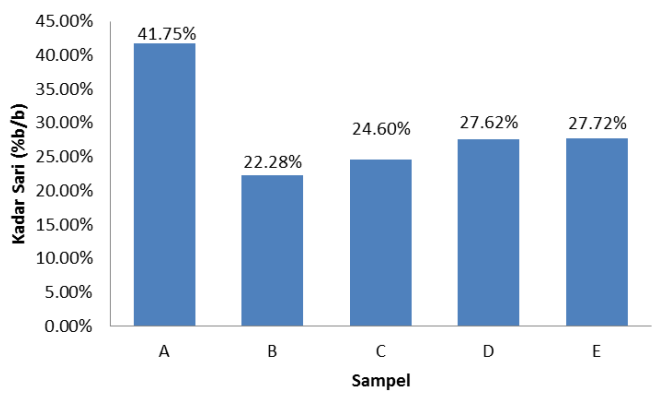

Gambar 7. Kadar Sari Kopi Bubuk

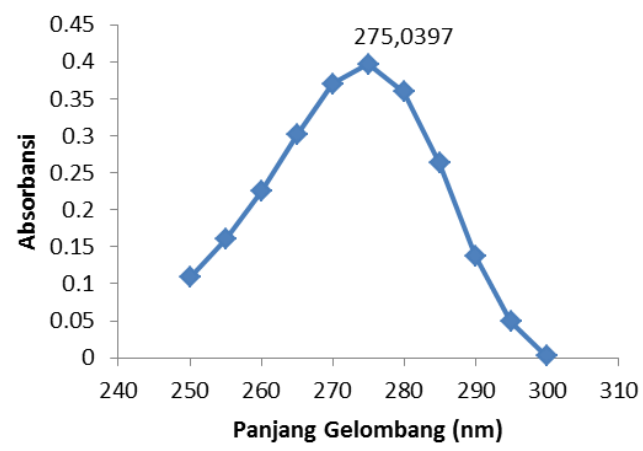

Gambar 8. Panjang Gelombang Maksimum Kafein

\section{Kadar Kafein}

Pada penelitian ini, penentuan kadar kafein dilakukan dengan metode spektrofotometri karena lebih efisien (Sabrina et al., 2012). Pengukuran dilakukan padan anjang gelombang maksimuam, yaitu $275 \mathrm{~nm}$ yang berada pada daerah UV (Gambar 8). Hasil penelitian kadar kafein pada ke lima sampel masih memenuhi standar yang diizinkan berdasarkan SNI 013542-2004 tentang kopi bubuk yaitu 0,92-2 $\%$ b/b. Kadar kafein tertinggi diperoleh pada sampel A sebesar 1,42\% dan kadar kafein terendah pada sampel E sebesar $0,71 \%$, dimana pada nilai $0,71 \%$ masuk ke dalam persyaratan ke II SNI 01-3542-2004 yaitu dengan syarat kadar kafein yang dihasilkan sebesar $0,45-2.0 \% \mathrm{~b} / \mathrm{b}$.

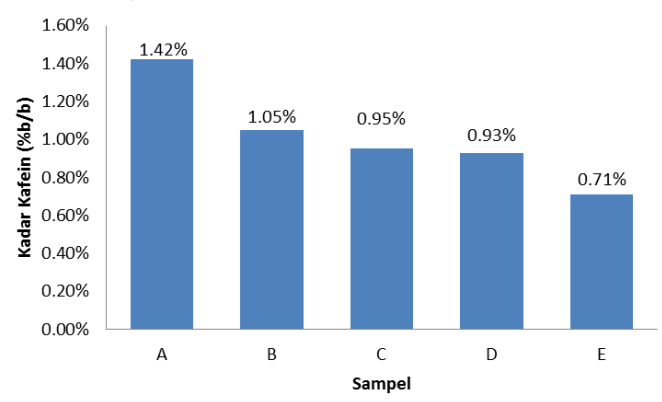

Gambar 9. Kadar Kafein Kopi Bubuk

Salah satu faktor yang mempengaruhi kadar kafein kopi yaitu varietasnya. Kopi robusta setelah penyangraian mempunyai kadar kafein yang tinggi yaitu $2 \%$ b/b dibandingkan kopi arabika setelah penyangraian yang mempunyai kadar kafein yang lebih kecil yaitu $1 \%$ b/b (Clarke dan Macrae, 1987). Menurut Farida et al. (2013) kadar kafein menurun seiring dengan lamanya waktu fermentasi. Kadar kafein juga berkurang seiring penguraian protein yang meningkatkan asam amino bebas (Macrone, 2004).

\section{KESIMPULAN}

Kadar kafein tertinggi untuk kopi bubuk dari hasil fermentasi menggunakan bakteri asam laktat yaitu sampel $\mathrm{C}$ sebesar $0,95 \%$ dan yang terendah pada sampel $\mathrm{E}$ yaitu $0,71 \%$. Kadar sari tertinggi terdapat pada sampel E sebesar 27,72\% dan kadar sari terendah pada C sebesar 24,60\%. Hasil kadar air tertinggi terdapat pada sampel $\mathrm{C}$ sebesar $4,56 \%$ dan kadar terendah pada sampel E sebesar 4,26\%. Kadar abu tertinggi terdapat pada sampel kopi C sebesar 4,98\% dan kadar abu terendah pada E sebesar 4,43\%. Nilai derajat keasaman $(\mathrm{pH})$ tertinggi didapatkan pada sampel B 
yaitu sebesar 6,19 dan terendah pada sampel A yaitu 5,41. Hasil uji menunjukkan bahwa kopi bubuk arabika dengan proses fermentasi enggunakan bakteri asam laktat memenuhi syarat SNI 01-3542-2004 pada parameter kadar air, kadar sari, kadar abu dan kadar kafein.

\section{DAFTAR PUSTAKA}

Badan Standardisasi Nasional [BSN]. (2004). SNI-01-3542-2004 Kopi Bubuk. BSN.

Badan Standardisasi Nasional [BSN]. (2008). SNI-01-2907-2008 Biji Kopi. BSN.

Badan Standardisasi Nasional [BSN]. (2004). SNI-01-2891-2004 Cara Uji Makanan dan Minuman. BSN.

Buffo, R.A. \& Cardelli-Freire, C. (2004). Coffee flavour: An overview. Flavour and Fragrance Journal, 19, 99-104.

Board, R. G. 1983. A Modern Introduction to Food Microbiology 1st ed.,: 1-50. Blackwell Scientific Publications. United States.

Clarke, R. J. dan Macrae, R. (1985). Coffee Volume 6 Commercial and Technico-Legal Aspects. Elsevier Applied Science, London and New York.

Clarke, R.J. dan Macrae, R. (1987). Coffee Volume 1 Coffee Chemestry. Elsevier Applied Science, London and New York.

Farida, A., Evi, R., Kumoro, A. C. (2013). Penurunan Kadar kafein dan asam Total pada biji kopi robusta menggunakan teknologi fermentasi anaerob fakultatif dengan mikroba Nopkor MZ-15. Jurnal Teknologi Kimia dan Industri, 2 (3), 70-75.

Fitri, N.S. (2008). Pengaruh Berat dan Waktu Penyeduhan terhadap Kadar
Kafein dari Bubuk Teh (Skripsi). Fakultas Matematika dan Ilmu Pengetahuan Alam Universitas Sumatera Utara, Medan.

Frank, H. A., dan Cruz, A.S.D. (1996). Bacteria Responsible for Mucilage Layer Decomposition in Kona Coffee Cherries. http://www.aem.asm.org.

Hadipernata, M., Nugraha, S. (2012). Identifikasi fisik, kimia dan mikrobiologi biji kopi luwak sebagai dasar acuan teknologi proses kopi luwak artificial. J Kementer Pertan. $372,117-121$

Hoffmann, J. (2014). The World Atlas of Coffee: From Beans to Brewing Coffees Explored, Explained and Enjoyed. Firefly Books. North America

Kustiyah, L. (1985). Mempelajari Beberapa Karakteristik Kopi Bubuk dari Berbagai Jenis Cacat Biji Kopi (Skripsi). Fakultas Teknologi Pertanian, Bogor.

Macrone, M. F. (2004). Composition and Properties of Indonesian Palm Civet Coffee (Kopi Luwak) and Ethiopian Civet Coffee. Department of Food Science, Ontario Agricultural College, Guelph, Ont., Canada.

Martin, M.J., Pablos, F., Gonzales, A.G.( 1999). Characterization of Arabica and Robusta Roasted coffe varieties and mixture resolution according to their metal content. Food Chemistry, $66,365-370$.

Muchtadi, D. (2010). Evaluasi Nilai Gizi Pangan. Pusat Antar Universitas Pangan dan Gizi (Skripsi).Institut Pertania Bogor, Bogor.

Mulato, S. (2002). Pelarutan Kafein Biji Robusta dengan Kolom Tetap Menggunakan Pelarut Air. Pelita Perkebunan. Jakarta. 
Murthy, P. S., dan Naidu, M. (2011). Improvement of Robusta Coffee Fermentation with Microbial Enzymes. European Journal of Applied Sciences, 3 (4): 130-139

Najiyati, S dan Danarti. (2001). Kopi Budidaya dan penanganan Lepas Panen. Penebar Swadaya. Jakarta.

Nopitasari, I. (2010). Proses Pengolahan Kopi Bubuk (Campuran Arabika dan Robusta) Serta Perubahan Mutunya Selama Penyimpanan (Skripsi). Fakultas Teknologi Pertanian, Institut Pertanian Bogor. Bogor.

Panggabean, E. (2011). Buku Pintar Kopi. PT Agro Media Pustaka. Jakarta.

Pastiniasih, L. (2012). Pengolahan Kopi Instan Berbahan Baku Kopi Lokal Buleleng, Bali (Campuran Robusta dan Arabika) (Skripsi). Fakultas Teknologi Pertanian, Institut Pertanian Bogor, Bogor.

Rachmawati, T. (2010). Pengaruh Penambahan Bahan Aditif Dalam Proses Pengolahan Kopi Bubuk dan Perubahan Mutunya Selama Penyimpanan (Skripsi).Institut Pertanian Bogor, Bogor.

Sabrina, K., Wonorahardjo, S., Zakia, N. (2012). Perbandingan Metode Spektrofotometri UV-Vis dan KCKT (Kromatografi Cair Kinerja Tinggi) pada Analisis Kadar Asam Benzoat dan Kafein dalam Teh Kemasan. Jurnal UNM. Malang.
Siswoputranto, P. S. (1993). Kopi Internasional dan Indonesia. Kanisius. Semarang.

Suarez-Quiroz, M.L.; O. Gonzalez-Rios; E.I. Champion-Martinez \& O. Angulo. (2008). Effects of lactic acid bacteria isolated from fermented coffee (Coffea arabica) on growth of Aspergillus ochraceus and Ochratoxin a production. Proceeding 22nd International Conference on Coffee Science Campinas, 542-546.

Towaha, J dan Rubiyo. (2016). Mutu Fisik Biji dan Citarasa Kopi Arabika Hasil Fermentasi Mikrob Probiotik Asal Pencernaan Luwak. J. TIDP, 3(2), 61-70.

Usman, D., Suprihadi, A., dan Kusdiyantini, E.. (2015). Fermentasi Kopi Robusta (Coffea canephora) Menggunakan Isolat Bakteri Asam Laktat Dari Feces Luwak Dengan Perlakuan Lama Waktu Inkubasi. Jurnal Biologi, 4 (3), 31-40.

Wilujeng, A. A. T, dan Wikandari, P. R. (2013). Pengaruh Lama Fermentasi Kopi Arabika ( coffea arabica) dengan Bakteri Asam Laktat Lactobacillus Plantarium B1765 Terhadap Mutu Produk. UNISA Journal of Chemistry, 2 (3), 1-10.

Yeretzian, C., Pascual, E.C., dan Goodman, B.A. (2012). Effect of roasting condition and grinding on free radical contents of coffee beans stored in air. Food Chemistry, 131, 811-816. 